\title{
REPAIR OF VESICOVAGINAL FISTULA: EXPERIENE OF 30 CASES AND ANALYSIS OF OUTCOME PREDICTORS
}

\author{
MRINMOY BISWAS ${ }^{1}$, SHARIF MOHAMMAD WASIM UDDIN ${ }^{2}$, JASMINE SHARIFA ${ }^{3}$, SHARMISHTHA \\ GHOSA $^{4}$, AKM MUSA BHUIYAN ${ }^{5}$, KARTIK CHANDRA GHOSH ${ }^{6}$
}

\begin{abstract}
:
Objective:To find out the predictors of outcome of vesicovaginal fistula repair.

Method: From 2013 t0 2015, thirty patients with vvf from different hospitals were managed surgically by different approach by single surgeons.

During evaluation patients records, the duration of vvf,time of surgical repairs, site of fistulas, positionof fistulas, approach of repairs, ureteric stenting, and catheteruzation were considered. A univariate analysis was used to assess individual variables, by the chi squared test andsignificant variables found in univariate analysis were considered in a mulivariate analysis.
\end{abstract}

Result: Among 30 cases $90 \%$ were successful repair. We consider the following variables to be important risk factors like history of previous repair,timeof surgery, site of fistulas and surgical approach.

Conclusion: Earlier correction of vvf, abdominal approach, high variety and primary repair has good outcome.

Key words: Genitourinary fistula, VVF.

Bangladesh J. Urol. 2019; 22(2): 136-140

\section{Introduction:}

Female genital fistula is a serious medical condition in which a perforation develops either between most commonly bladder and vagina(VVF), between rectum and vagina (Recto-vaginal fistula) or combination of both [1]. Prolonged and obstructed labour was long considered to be the leading cause of vesicovaginal fistula in woman in developing countries. In developed countries iatrogenic VVF is a complication of many procedures, comprising up to $90 \%$ of the VVF of those countries[2]. In Egypt as well as in other countries obstetric trauma was considered the leading cause of

1. Department of Urology, Faridpur Medical College,

2. Department of Urology, Sir Salimullah Medical College Mitford Hospital,

3. Department of Gynaecology \& Obstetrics, Faridpur Medical College,

4. Department of paediatrics, Kurmitola general hospital,

5. Department of Urology, Dhaka Medical College, Dhaka,

6. Department of Urology, Bangabandhu Sheikh Mujib Medical University, Dhaka

Correspondence: Dr. Mrinmoy Biswas, MS (Urology), Assoc. Professor, Department of Urology, Faridpur Medical College Faridpur. Mob.+88-01711904588, E-mail: b_mrinmoy@yahoo.com Received: 05 February 2019
VVF. In an important report, Mahfouz, a pioneer obstetrics and gynaecology, reported on almost 1000 cases of VVF, most of them caused by pressure necrosis during difficult prolonged or obstructed vaginal deliveries. In the last three decades, obstetric trauma has become less important as a major cause of iatrogenic VVF[3,4].

Female genital fistula is no longer prevalent in the developed world, but remains a common public health concern in developing countries. There are no good estimates of the burden of fistula, but the most recent estimates of its prevalence range from one to two million worldwide based on reviews by Stanton et al. and Adler et al.[5,6,7,8]. Although the majority of genitourinary fistulas can be closed surgically, the likelihood of successful closure depends on the characteristics and severity of the fistula, skill of the surgeon and probably, surgical methods used[9]. Many fistula surgeons have developed their own methods through experience, thus, perioperative procedures vary widely across surgeons and facilities[10]. Few studies have examined the comparative effectiveness of different perioperative 
Repair of Vesicovaginal fistula: Experiene of 30 cases and analysis of outcome predictors

interventions related to the surgical management of genitourinary fistulas[11,12] . One aspect of surgical repair of in particular, the route of repair undertaken, is of critical research interest, as the abdominal (versus Vaginal) approach may be associated with longer term hospitalization, urinary infection and increased blood loss[13,14] .

Recommendations vary with regard to whether a vaginal or abdominal surgical approach should be used for fistula repair. Vaginal approaches are generally thought to be appropriate for any fistula located between the bladder and the vagina, with some fistula surgeons claiming to be able to repair all fistulas by the vaginal route[15,16,17] . However, abdominal approaches are also often considered to be most appropriate for complex fistulas, with published indications for an abdominal rout of repair including: a small capacity or poorly compliant bladder which requires bladder augmentation; fistulas involving or close to the ureteric orifice( particularly if ureteric reimplantation is required); vaginal stenosis or other factors inhibiting adequate vaginal exposures of the fistula; size; trigonal or supratrigonal location; intracervical location; and concomitant abdominal pathology. However, the choice of surgical approach remains, to some extent, a matter of surgeon preference or training and experience of the surgical team[13,16,18,19,20]. The aim of the present study was to assess factors possibly affecting success of surgical correction of VVF.

\section{Materials and Methods:}

This is a prospective study and it included 30 patients with VVF who had complete records between 2013 and 2015 done by a single surgeon in different hospitals. At the time of diagnosis all patients had a local examination, basal biochemical profile (complete blood count, serum creatinine and urine analysis). The IVU and ultrasonography of kidney, ureter and bladder region were used for documentation of reno-ureteric configuration. An ascending cystogram with anteroposterior and lateral view was taken. The three gauze test with methylene blue instilled in the bladder to detect fistulae undetected on cystogram. Urethrocystoscopic examination at the time of surgery was a routine step. In the evaluation of the patient records, the duration of the VVF, the cause and any previous repair were all documented. The duration of urethral catheter drainage and use of ureteric stent and duration were recorded. The site and the number of fistulous openings were also recorded. The VVF was considered "Low" when the fistulous opening was below the inter ureteric ridge, "high" when above this line and a fistula at the bladder neck was considered as a separate entity. The approach (Abdominal or vaginal) was recorded and the use of an interposition flap was checked.

In the abdominal approach we used a midline infraumbilical incision and transvesical approach , while in a vaginal approach we identified the fistula opening using an Auvurd weighted vaginal retractor, insertion of a $14 \mathrm{fr}$ Foley catheter in the fistulous tract and complete excision of the tract, with a two layer closure of the bladder and vaginal mucosa. Discharge data were reviewed and only those patients who were reported continent were considered as a success.

The mean age of the patients was 23.8 years. Four $(13 \%)$ patients had a VVF after an abdominal hysterectomy, 20(67\%) after Caesarean section and $6(12 \%)$ after a difficult vaginal delivery. In all, $6(20 \%)$ patients had a previous failed repair of the VVF elsewhere.

A univariate analysis was used to assess individual variables, with the chi-squared test; those variables significant on univariate analysis were considered in a multivariate analysis, using logistic linear regression. In all tests, significance was indicated at $\mathrm{P}<0.005$.

\section{Results}

The duration of the VVF until treatment was $<6$ months in $25(83.3 \%)$ patients and $>6$ months in $5(16.70)$ patients. On urethrocystoscopic examination $24 \mathrm{VVF}$ $(80 \%)$ were high, 4 VVF $(20 \%)$ were low and none was at the bladder neck. In $6(20 \%)$ cases have previous repair and $24(80 \%)$ cases were first time repair. $27(90 \%)$ patients have single fistulous opening and $3(10 \%)$ patients have two fistulous openings. An abdominal approach was used in $24(80 \%)$ patients and no interposition of omental or peritoneal flaps was used. Vaginal approach was used in 6(20\%) patients.

The urethral catheter was left in situ for 21 days in $16(53.3 \%)$ cases, for 28 days in $13(43.3 \%)$ cases and $>28$ days in $1(3.3 \%)$ case. In $9(30 \%)$ patients ureteric stents were used and in $21(70 \%)$ patients without stent.

Based on discharge date and follow up visits, the success rate was $90 \%$ and failure rate was $10 \%$. We considered the following variables to be important risk factors and available for all patients, a history of previous repair, duration of the VVF until treatment (<vs> 6 months), position of the VVF on urethrocystoscopy (high, low, at bladder neck), number of fistulous opening (single vs multiple), approach of surgery (abdominal vs vaginal), duration of the urethral 
catheterization ( 21 days, 28 days \& more than 28 days) and ureteric stenting.

In a univariate analysis, previous repair, the duration of VVF until treatment, position of fitulous opening and surgical approach had a significant effect on the success of surgery, with $P=0.033$,
$0.014,0.033$ and 0.033 respectively. Table 1 shows the results of the univariate analysis. Among those variables significant on univariate analysis, only previous repair and site of fistula had a significant effect in the multivariate analysis using logistic linear regession (Table II).

Table-I

Univariate analysis of local variables affecting the success of VVF repair.

\begin{tabular}{|c|c|c|c|c|}
\hline Variables & $\begin{array}{c}\text { Failed }(n=3) \\
n(\%)\end{array}$ & $\begin{array}{c}\text { Success }(\mathrm{n}=27) \\
\mathrm{n}(\%)\end{array}$ & $\begin{array}{c}\text { Total }(\mathrm{n}=30) \\
\mathrm{n}(\%)\end{array}$ & $P$ value \\
\hline \multicolumn{5}{|c|}{ Previous repair } \\
\hline Yes & $2(66.7 \%)$ & $4(14.8 \%)$ & $6(20.0 \%)$ & \multirow[t]{2}{*}{$0.033^{s}$} \\
\hline No & $1(33.3 \%)$ & $23(85.2 \%)$ & $24(80.0 \%)$ & \\
\hline \multicolumn{5}{|c|}{ Time of surgical intervention } \\
\hline$<6$ months & $1(33.3 \%)$ & $24(88.9 \%)$ & $25(83.3 \%)$ & \multirow[t]{2}{*}{$0.014^{\mathrm{s}}$} \\
\hline$>6$ months & $2(66.7 \%)$ & $3(11.1 \%)$ & $5(16.7 \%)$ & \\
\hline \multicolumn{5}{|c|}{ Site of fistula } \\
\hline High & $1(33.3 \%)$ & $23(85.2 \%)$ & $24(80.0 \%)$ & \multirow[t]{2}{*}{$0.033^{\mathrm{s}}$} \\
\hline Low & $2(66.7 \%)$ & $4(14.8 \%)$ & $4(20.0 \%)$ & \\
\hline \multicolumn{5}{|c|}{ Fstiulous openings } \\
\hline Single & $3(100.0 \%)$ & $24(88.9 \%)$ & $27(90.0 \%)$ & \multirow[t]{2}{*}{$0.543^{n s}$} \\
\hline Multiple & $0(0.0 \%)$ & $3(11.1 \%)$ & $3(10.0 \%)$ & \\
\hline \multicolumn{5}{|l|}{ Approach } \\
\hline Vaginal & $2(66.7 \%)$ & $4(14.8 \%)$ & $6(20.0 \%)$ & \multirow[t]{2}{*}{$0.033^{s}$} \\
\hline Abdominal & $1(33.3 \%)$ & $23(85.2 \%)$ & $24(80.0 \%)$ & \\
\hline \multicolumn{5}{|c|}{ Ureteric stents } \\
\hline Yes & $1(33.3 \%)$ & $8(29.6 \%)$ & $9(30.0 \%)$ & \multirow[t]{2}{*}{$0.894^{\mathrm{ns}}$} \\
\hline No & $2(66.7 \%)$ & $19(70.4 \%)$ & $21(70.0 \%)$ & \\
\hline \multicolumn{5}{|c|}{ Catheter duration (days) } \\
\hline 21 days & $1(33.3 \%)$ & $15(55.6 \%)$ & $16(53.3 \%)$ & \multirow[t]{3}{*}{$0.677^{n s}$} \\
\hline 28 days & $1(66.7 \%)$ & $11(40.7 \%)$ & $13(43.3 \%)$ & \\
\hline$>28$ days & $0(0.0 \%)$ & $1(3.7 \%)$ & $1(3.3 \%)$ & \\
\hline
\end{tabular}

ns $=$ not significant, $s=$ significant, $p$ value $<0.05$ considered as a significant level

Table-II

Multivariate analysis, using logistic linear regression

\begin{tabular}{lcccc}
\hline Variables & Regression estimate, $\beta$ & SE & Exp. B & P value \\
\hline Previous repair & 0.311 & 0.121 & 0.415 & $0.016^{\mathrm{s}}$ \\
Time of surgery & -.209 & 0.141 & -.260 & $0.152^{\mathrm{ns}}$ \\
Site of fistula & -.310 & 0.137 & -.413 & $0.033^{\mathrm{s}}$ \\
Surgical approach & 0.197 & 0.126 & -.171 & $0.130^{\mathrm{ns}}$ \\
\hline
\end{tabular}

$\mathrm{ns}=$ not significant, $\mathrm{s}=$ significant, $\mathrm{p}$ value $<0.05$ considered as a significant level 


\section{2(2) 2019}

Repair of Vesicovaginal fistula: Experiene of 30 cases and analysis of outcome predictors

\section{Discussion:}

In one study it was found that the leading cause of VVF was obstetric trauma where the mean age of patients was 15.5 years[21]. In another study from Ethiopia $40 \%$ of patients in the study cohort of 193 were teenagers and $95.3 \%$ of the VVF resulted from obstetric trauma[22]. In the current study, also the leading cause of VVF was obstetric trauma \& mean age of patients was 23.8 years.

Waaldijk tried immediate closure by different techniques of repair got success rate of $95.2 \%$ and $86.8 \%$ in a study by Gessessew and Mesfin[23].

Chapple $\mathrm{C}$ and Turner -Warwick $\mathrm{R}$ stated that the success of surgical correction of VVF was compromised by tissue ischemia, radiation and recurrence[24]. None of our patients had previous pelvic irradiation but $6(20 \%)$ patients had previous failed repair of VVF elsewhere. Previous VVF repair was a significant factor affecting the outcome of surgery both in uni \& multivariate analysis. Another important factor was long median duration of the VVF. $<6$ months duration group had a success rate of $88.9 \%$ \& $>6$ months group had $11.1 \%$, might be due to prolonged defunctioning of the bladder.

While an abdominal approach is considered by some to be the reference treatment for simple \& complex VVF, other consider the vaginal route as a routine approach for repair, considering the morbidity of the abdominal route. However, Eilber et al. concluded that the approach chosen for VVF repair should be that with which the surgeon is most comfortable[25,26,27]. In our study clearly showed that the surgical approach affected the outcome of surgery of vaginal approach was associated with failure rates than abdominal approach. In our study another factor revealed that affected the outcome was position of the fistulous opening, high varieties had higher success rate.

\section{Conclusion:}

Surgical correction of the VVF is more successful when done earlier. Abdominal approach seems to be more successful technique and recurrent VVF being associated with lower success rates than primary repair. Fistulous opening at high in position also has good result.

\section{References:}

1. Delamu A, Diallo M, Beavogui A H et al. Good clinical outcome from a7- year holistic programme of fistula repair in Guinea. Tropical Medicine and International Health. 2015:20:6:813-819

2. Garthwaite M, Harris N. Vesicovaginal fistulae. Indian J Urol 2010:26:253-6.

3. Mahfouz N. Urinary fistulae in women. J Obstet Gynaecol Br Emp 1957:74:23-8.

4. Bassem S W, Kamal M M. Repair of vesicovaginal fistula: Single-centre experience and analysis of outcome predictors. Arab J Urol;2011:9:135-138.

5. Wall LL. Obstetric fistula is a "neglected tropical disease". PLoS Negl Trop Dis 2012:6:1769.

6. Osotimehin B. Obstetric fistula: ending the health and human rights tragedy. Lancet 2013:381:17021703.

7. Stanton C, Holtz S A, Ahmed S. Challenges in measuring obstetric fistula. Int J Gynaecol Obstet 2007:99(Suppl 1):S4-S9.

8. Adler AJ, Ronsmans C, CalvertC, Filippi V. Estimating the prevalence of obstetric fistula: a systematic review and meta analysis. BMC Pregnancy Childbirth 2013:13:246.

9. Wall. LL, Arrowsmith SD, Briggs ND, Browning A, Lassey A. The obstetric vesicovaginal fistula in the developing world. Obstet Gynaecol Surv 2005:60:S-3-51.

10. Brownng A. The circumferential obstetric fistula:characterstics, management and outcomes. BJOG2007:114:1172-6.

11. Narods R, Browning A, Member B. Duration of bladder catheterization after surgery for obstetric fistula. Int J Gynaecol Obstet 2008: 103: 30-2.

12. Kirschner C, Yost K, Du H, Karshima J, Arrowsmith S, Wall L. Obstetric fistula: the ECWA Evangel VVF Center surgical experience from Jos, Nigeria. IntUrogynaecol J 2010:21:1525-33.

13. KapoorR, Ansari MS, Singh P, Gupta P,Khurana $\mathrm{N}$, Mandhani A, et al. Management of vesicovaginal fistula: an experience of 52 cases with a rationalized algorithm for choosing the transvaginal or transabdominal approach. Indian J Urol 2007:23:372-6.

14. Morhason- Bello IO, Ojengbede OA, Adedokun BO, Okunlola MA, Oladokun A. Uncomplicated midvaginal vesico-vaginal fistula repair in Ibadan: a comparison of the abdominal and vaginal routes. Ann Ibadan Postgrad Med 2008:6:39-43. 
15. Zombon JP, Batezini NS, Pinto ER, Skaff M, Girotti ME, Almeida FG. Do we need new surgical techniques to repair vesicovaginal fistulas? Int Urogynaecolol J Pelvic Floor Dysfunct 2010:21:337-42.

16. Carr LK, Webster GD. Abdominal repair of vesicovaginal fistula. Urology 1996:48:10-1

17. Hencock B, Browning A. Practical Obstetric fistula Surgery. London: Royal Society of Medicine Press, 2009.

18. Genadry RR, Creanga AA, Roenneburg ML, Wheeler CR. Complex obstetric fistula. Int J Gynaecol Obstet 2007: 99(Suppl.1):S51-6-9

19. Creanga AA, Genadry RR. Obstetric fistula: a clinical review. Int J Gynaecol Obstet. 2007:99(Suppl.1) S40-6.

20. Hill EC. Repair of vesico-vaginal fistula. Calif Med 1962:97:216

21. Wall LL, Karshima JA, Kirschner C, Arrowsmith SD. The obstetric vesicovaginal fistula. Characterstics of 899 patients from Jos. Nigeria Am J Obstet Gynaecol 2004:190:1011-9
22. Gessessew A, Mesfin M. Genitourinary and rectovaginal fistulae in Adigrat Zonal Hospital, Tigray, North Ethiopia. Ethiop Med J 2003:41: 12330.

23. Waaldijk K. The immediate management of fresh obstetric fistulas. Am J Obstet Gynaecol 2004:191:795-9.

24. Chapple C, Turner- Warwick R. Vesico-vaginal fistula. BJU Int 2005:95:193-214.

25. Morgan EK. Transabdominal, transperitoneal, transvesical repair of recurrent vesicovaginal fistula. Br J Urol 1970:42:743-4.

26. Mondet F, Chartier- Kastler EJ, Conort P, Bitker MO, Chatelain F, Richard F. Anatomic and functional results of transperitoneal - transvesicl vesicovaginal fistula repair. Urology 2001:58: 882-6.

27. Eilber KS, Kavaler E, Rodriguiz LV, Rosenblum $\mathrm{N}, \mathrm{Raz} \mathrm{S}$. Ten years experience with transvaginal, vesicovaginal fistula repair using tissue interposition. J Urol 2003:169:1033-6. 